\title{
Factors affecting levels of volatile 4-alkyl branched-chain fatty acids in sheep milk from 2 contrasting farming systems in New Zealand
}

\author{
Fei Teng, ${ }^{1,2}$ Mariza G. Reis, ${ }^{1}$ Marita Broadhurst, ${ }^{3}$ Kirill Lagutin, ${ }^{4}$ Linda Samuelsson, ${ }^{1}$ Ying Ma, ${ }^{2}$ \\ David Stevens, ${ }^{5}$ and Li Day ${ }^{1,2 *}$ \\ ${ }^{1}$ Grasslands Research Centre, AgResearch Ltd., 11 Dairy Farm Road, Palmerston North 4442, New Zealand \\ ${ }^{2}$ School of Chemistry and Chemical Engineering, Harbin Institute of Technology, 92 Xidazhi Street, Nangang District, Harbin 150001, China \\ ${ }^{3}$ Ruakura Research Centre, AgResearch Ltd., 10 Bisley Road, Hamilton 3214, New Zealand \\ ${ }^{4}$ Callaghan Innovation, 69 Gracefield Road, Lower Hutt 5010, New Zealand \\ ${ }^{5}$ Invermay Research Centre, AgResearch Ltd., 176 Puddle Alley, Mosgiel 9053, New Zealand
}

\begin{abstract}
Knowledge of factors influencing the levels of 4-alkyl branched-chain fatty acid (vBCFA), and consequently the "sheepy flavor" intensity of New Zealand sheep milk, is currently limited. In this study, we investigated the effects of 2 contrasting farming systems (fully housed/ mid-lactation or pasture-grazed/late lactation) on the levels of vBCFA in sheep milk on a commercial farm in the North Island of New Zealand. Fully housed/ mid-lactation ewes were housed $24 \mathrm{~h} / \mathrm{d}$ and fed a total mixed ration. Pasture-grazed/late-lactation ewes were grazed $24 \mathrm{~h} / \mathrm{d}$ and offered approximately $40 \%$ supplements because of poor pasture growth resulting from dry and hot climatic conditions. Any effects of genetics, age, lactation stage, feed composition, lambing date, or the environment in the housing barn or outdoors were confounded. The results obtained in this study were descriptive rather than definitive, because of the limitations of the experimental design. Levels of 4-methyloctanoic acid and 4-methylnonanoic acid in milk from fully housed/mid-lactation ewes increased during the trial period, but remained low in milk from pasturegrazed/late-lactation ewes. Levels of 4-ethyloctanoic acid in milk from the 2 groups of ewes were comparable throughout the trial. Increases in levels of 4-methyloctanoic acid and 4-methylnonanoic acid in sheep milk were associated with lactation stage and the proportion of lucerne silage fed to ewes. The level of free-form 4-ethyloctanoic acid was positively correlated with the proportion of soy meal in the diet and negatively correlated with the proportion of barley. Milk from fully
\end{abstract}

Received June 30, 2019.

Accepted November 3, 2019.

*Corresponding author: li.day@agresearch.co.nz housed/mid-lactation ewes had a higher flavor values than milk from pasture-grazed/late-lactation ewes because of its higher total amounts of vBCFA.

Key words: ruminant milk, fatty acid profile, volatiles, flavor intensity

\section{INTRODUCTION}

New Zealand dairy sheep production is generally associated with high pasture intake and is based on rotational grazing of perennial ryegrasses (Lolium perenne) and white clover (Trifolium repens; Rugoho et al., 2014). However, environmental extremes (heat or cold) may reduce milk yield and change milk composition (Nasrollahi et al., 2017). For example, in summer, farms in warm regions face challenges of high solar radiation, high ambient temperatures, and decreasing pasture quality and quantity. These environmental and nutritional factors in turn affect sheep milk yield (Bliss et al., 2018) and milk composition. A potential way to avoid these seasonal variations is to devise farming systems that can mitigate the negative effects of harsh conditions (i.e., summer heat or winter cold) while allowing farmers to control diet quality and quantity by combining high-quality in situ forage with supplements. An example of this approach is a fully housed farming system based on a grass and lucerne silage diet developed to increase milk yield (yield and consistent composition) while maintaining good animal health and welfare (Bliss et al., 2018).

Many factors affect milk yield and milk composition, including genetics (breeds and genotype), physiological properties (age, lambing, BW, number of lambs, and stage and number of lactations), management (feeding regimen), and environment (Garg et al., 2013; Buccioni et al., 2015; Nasrollahi et al., 2017; Grant and Ferraretto, 2018). Lactation stage and feeding regimen have the greatest influence (Caja and Bocquier, 2000; Pulina et 
al., 2007). In general, daily milk yield decreases by 2 to $4 \%$ per week as lactation advances (Fuertes et al., 1998; Oravcová et al., 2006; Pulina et al., 2007; Kuchtík et al., 2008; Mioč et al., 2009; Novotná et al., 2009). Although this decrease in milk yield can be slowed by a diet of high energy concentration (Caja and Bocquier, 2000), such a diet is often high in carbohydrates and can cause a decrease in milk fat (Fuertes et al., 1998; Caja and Bocquier, 2000). Therefore, intensive indoor systems with high concentrate input generally produce milk with lower fat content than pasture-based farming systems (Caja and Bocquier, 2000; Morand-Fehr et al., 2007; Sanz Sampelayo et al., 2007; Raynal-Ljutovac et al., 2008). These changes in milk composition are associated with variations in the concentrations and proportions of volatile fatty acids (e.g., acetate, propionate, and butyrate) after ruminal fermentation of different feeds (Haenlein and Wendorff, 2008; Garg et al., 2013; Buccioni et al., 2015; Ellison et al., 2017; Grant and Ferraretto, 2018).

Factors such as lactation stage, season, breed, genotype, and feeding regimen can also influence the amounts and composition of fatty acids in sheep milk (Sanz Sampelayo et al., 2007; Raynal-Ljutovac et al., 2008). The effects of feeding, basic roughage, and lipid supplementation on variations in the fatty acid composition of sheep milk has been extensively studied (Morand-Fehr et al., 2007; Sanz Sampelayo et al., 2007; Buccioni et al., 2015; Buccioni et al., 2017). As in cows, fresh grass strongly influences the fatty acid composition of sheep milk by increasing the proportions of MUFA and PUFA (Cabiddu et al., 2005; Morand-Fehr et al., 2007; Sanz Sampelayo et al., 2007; Grant and Ferraretto, 2018).

Sheep milk and meat has a characteristic "sheepy" flavor that defines the consumer experience of sheep milk and meat products (Andrés et al., 2018; Teng et al., 2018). This characteristic sheepy flavor is associated mainly with 3 volatile 4 -alkyl branched-chain fatty acids (vBCFA): 4-methyloctanoic acid (4-Me-8:0), 4-ethyloctanoic acid (4-Et-8:0), and 4-methylnonanoic acid (4-Me-9:0; Salles et al., 2002; Teng et al., 2018). We found significant positive correlations (correlation coefficients $0.676-0.876 ; P<0.001$ ) between levels of vBCFA (total amounts and free-form levels) and the sheepy flavor in a previous sensory study from our laboratory (data not published). Monomethyl-substituted fatty acids (e.g., 4-Me-8:0 and 4-Me-9:0) are synthesized de novo by the use of methylmalonyl-coenzyme A ( CoA) in chain lengthening with acetyl-CoA (Massart-Leën et al., 1983; Vlaeminck et al., 2006), using propionate as a precursor. Both the liver and (to a lesser extent) the mammary gland synthesize vBCFA when propionate concentrations exceed the capacity of gluconeogenesis (Wong et al., 1975; Aschenbach et al., 2010). The biosynthesis pathway of 4-Et-8:0 is less known. It may follow the same biosynthesis pathway of monomethylsubstituted fatty acids, using butyrate as the precursor instead of propionate. Ethylmalonyl-CoA would be used as the primer instead of methylmalonyl-CoA (Ha and Lindsay, 1990; Kaffarnik et al., 2015). Feeding regimens could also affect the level of vBCFA in sheep milk and meat by affecting the concentrations and proportions of their precursors (i.e., propionate, butyrate). For example, feed supplements such as maize, barley, and legumes (e.g., lucerne) induce higher levels of vBCFA in sheep meat than pasture feed (Watkins et al., 2013). Lactation stage is another important factor affecting the levels of vBCFA in sheep milk. An increase in levels of free-form vBCFA in the milk of pasture-fed ewes in late lactation was observed in a previous study (Teng et al., 2018). Other factors, such as animal genetics, age, and sex could also contribute to variations in vBCFA levels in sheep milk and meat (Duncan and Garton, 1978; Salvatore et al., 2007; Watkins et al., 2013; Buccioni et al., 2017; Chikwanha et al., 2018).

The flavor intensity of sheep milk and meat products depends not only on vBCFA concentrations but also on their sensory thresholds (Charlotte et al., 1989; Salles et al., 2002; Salvatore et al., 2007; Teng et al., 2018). For example, 4-Et-8:0 contributes more than $70 \%$ to the sheepy flavor of sheep milk because its sensory threshold is 100 times lower than that of 4-Me-8:0 and 4-Me-9:0 (Salles et al., 2002; Salvatore et al., 2007; Teng et al., 2018). Odor activity values (OAV), calculated from the concentrations of free-form $\mathrm{vBCFA}$ relative to their sensory thresholds, can be used to estimate the flavor intensity of sheep milk. The total amount of vBCFA, which includes the free form and the esterified form (esterified in triacylglycerols, diacylglycerols, and monoacylglycerols) can also be used to calculate flavor values $(\mathbf{F V})$ and to determine their contribution to the flavor intensity of sheep milk products (e.g., cheese, yogurt, or milk powder; Kaffarnik et al., 2014). Freeform $\mathrm{vBCFA}$ can be released from hydrolysis of triacylglycerols, diacylglycerols, and monoacylglycerols during processing (e.g., fermentation and spray-drying).

This study aimed to investigate whether different farming and feeding systems might influence the levels of vBCFA in sheep milk. We trialed 2 contrasting farming systems (fully housed/mid-lactation and pasturegrazed/late lactation) on a commercial farm in the North Island of New Zealand. We also estimated the flavor intensity of milk and milk products from these 2 farming systems by comparing OAV and FV. The results from this study could provide new knowledge 
for dairy sheep farmers and sheep milk processors to understand factors that might be relevant to the flavor characteristics of sheep milk and milk products.

\section{MATERIALS AND METHODS}

This study took place in the summer from December 2016 to February 2017 on a commercial dairy sheep farm near Taupo on the North Island of New Zealand using East Friesian cross-bred ewes. The experiment compared 2 groups of lactating ewes managed $24 \mathrm{~h} / \mathrm{d}$ on a full supplement diet in a housing barn or on a mixed grazing/supplement diet at pasture. The study period consisted of a gradual transition period (December 22, 2016, to January 9, 2017), followed by a 7-wk trial period.

\section{Animals}

Animal ethics approval was obtained from the AgResearch Animal Ethics Committee (approval number 14081). Two groups of ewes were managed on pasture before the trial started. Because the trial was conducted on a commercial farm and to avoid the effect of changing social structure and hierarchies on animal welfare and milk production, the groups were not mixed for this study. Each group consisted of ewes of mixed ages $(1$ to $8 \mathrm{yr})$, and daily milk yield $(1.14 \pm 0.71 \mathrm{~L} / \mathrm{d}$ per ewe) was comparable between the 2 groups before the start of the trial.

The fully housed/mid-lactation group of 479 ewes was managed $24 \mathrm{~h} / \mathrm{d}$ in a housing barn. Of the ewes in this group, $90 \%$ were in mid lactation $(60 \mathrm{~d}<$ DIM $<$ $120 \mathrm{~d}$ ), $8 \%$ were in late lactation (DIM $>120 \mathrm{~d}$ ), and $2 \%$ were in early lactation (DIM $<60 \mathrm{~d}$ ). The average DIM in wk 0 was $88 \mathrm{~d}$. The pasture-grazed/late-lactation group of 604 ewes was grazed $24 \mathrm{~h} / \mathrm{d}$ and fed supplements when pasture growth was poor. These ewes were at 121 DIM in wk $0 ; 57 \%$ of ewes were in late lactation, $41 \%$ in mid-lactation, and $2 \%$ in early lactation.

\section{Transition, Dietary Allocations, and Animal Management}

Ewes were adjusted gradually from pasture grazing to the housing barn from December 22 (wk 0) to January 9. During the transition period, ewes were offered silage ad libitum in the shed while pasture allowance in the paddock was reduced.

During the trial period, the fully housed/midlactation ewes were managed $24 \mathrm{~h} / \mathrm{d}$ in a dedicated barn. The housing barn had a vented canvas roof and open sides to maximize air flow. The barn environment (e.g., temperature, humidity, and ammonia levels) was monitored and considered as a potentially confounding factor. The fully housed/mid-lactation ewes were fed a TMR twice daily, consisting of grass silage (Lolium perenne), lucerne silage (Medicago sativa), and a grainbased concentrate supplement of barley and soy meal. The pasture-grazed/late-lactation ewes were grazed 24 $\mathrm{h} / \mathrm{d}$ on pasture of perennial ryegrasses/white clover (Lolium perenne/Trifolium repens) and supplemented each day due to low pasture growth resulting from hot and dry climatic conditions. The supplements fed to the pasture-grazed/late-lactation ewes were the same as those fed to the fully housed/mid-lactation ewes, although the relative contributions were different. Natural shade was not available for the ewes in the paddocks. The amount of each ingredient fed to each group of ewes was recorded daily by the farm. The energy concentration of each ingredient in the TMR and the grazed forage was estimated by near-infrared reflectance spectroscopy according to the method published by Corson et al. (1999). The feed intake for each group of ewes was determined by a calculation using live weight and milk yield to determine total ME requirements (Agricultural Research Council and Commonwealth Agricultural Bureaux, 1980). The grazed forage intake of the pasture-grazed/late-lactation ewes was calculated as the difference between the total energy requirements and the energy offered by the supplements. The relative proportions of supplements fed to each group of ewes and the grazed forage fed to the pasture-grazed/mid-lactation ewes were then calculated by their intake relative to the total feed intake. The mean values of the proportion of each ingredient fed to the ewes for each week are summarized in Supplemental Table S1 (https://doi.org/10.3168/jds.2019-17192). For the fully housed/mid-lactation ewes, grass silage ( Lolium perenne) and lucerne silage (Medicago sativa) were the major ingredients, accounting for 23.9 to $63.9 \%$ and 18.4 to $60.3 \%$ of the diet during the trial period (wk 1-7), and barley and soy meal consisted of 11.0 to $21.1 \%$ and 0 to $8.62 \%$, respectively (Supplemental Table $\mathrm{S} 1)$. For the pasture-grazed/late-lactation ewes, grazed forage was predominant $(47.6-67.2 \%)$ in the diet during the trial period (wk 1-7), and barley and soy meal consisted of 18.3 to $30.8 \%$ and 0 to $3.16 \%$, respectively; lucerne silage accounted for only a small proportion of the diet in this group $(0-5.22 \%$, Supplemental Table S1). This approach, in a commercial setting, led to some confounding of the data and is discussed in the Statistical Analysis section.

\section{Sampling}

Bulk milk samples from each group were collected at the morning milking $(0530 \mathrm{~h})$ on the days of collection. 
Four replicate samples per group were collected in the transition period (wk 0, December 22, 2016), and then weekly throughout the trial (wk 1-7, from January 12 , 2017, to February 22, 2017) to make a total of 7 time points for evaluation of milk composition, fatty acid profile, and vBCFA concentrations.

\section{Daily Milk Yield, Live Weight, and BCS Measurements}

Individual daily milk yield was recorded automatically by in-line milk meters at transition (wk 0) and weekly over the 7 -wk trial period. The live weight and BCS (5-point scale) of ewes in each group were recorded at the start and end of the trial by a single operator as described in a previous study (Bliss et al., 2018).

\section{Chemicals}

Methanol, chloroform, n-hexane, cyclohexane, ethyl acetate (HPLC grade) and other reagents (analytical grade) were purchased from Thermo Fisher Scientific (Auckland, New Zealand). Standards of 4-Me-8:0, 4-Et8:0, and 4-Me-9:0 were purchased from Sigma-Aldrich (Castle Hill, Australia). A FAME mix standard GLC714 was purchased from Nu-Chek Prep (Elysian, MN).

\section{Milk Composition Analysis}

Total solids and protein and lactose contents in milk samples were analyzed using a MilkoScan FT1 analyzer (Foss, Hillerød, Denmark) and commercially (MilkTestNZ, Hamilton, New Zealand). Fat content was determined after freeze-drying the samples and extracting the total fat using accelerated solvent extraction (ASE 350; Dionex, Idstein, Germany) according to the method described in our previous study (Teng et al., 2018).

\section{Fatty Acid Analysis}

Milk fat was extracted using the method of Svennerholm and Fredman (1980), with some minor modifications. Sheep milk $(8 \mathrm{~g})$ was mixed with $24 \mathrm{~mL}$ of chloroform/methanol $(1: 2, \mathrm{vol} / \mathrm{vol})$ in a $40-\mathrm{mL}$ centrifuge tube and sonicated for $10 \mathrm{~min}$, followed by centrifugation for $10 \min \left(2,850 \times g, 25^{\circ} \mathrm{C}\right)$. The supernatant was further extracted with $12 \mathrm{~mL}$ of chloroform/methanol (1:1, $\mathrm{vol} / \mathrm{vol}$ ), and twice with $9 \mathrm{~mL}$ of chloroform/methanol $(2: 1, \mathrm{vol} / \mathrm{vol})$ for $10 \mathrm{~min}$ using ultrasonication. The lower layer from each extraction (consisting of lipids) was combined and transferred to a $100-\mathrm{mL}$ centrifuge tube and washed with water $(19 \mathrm{~mL})$ and $10 \%$ aqueous $\mathrm{KCl}(3 \mathrm{~mL})$, and then centrifuged for $10 \mathrm{~min}(2,850 \times$ $\left.g, 25^{\circ} \mathrm{C}\right)$. The lower layer was dried and constituted the crude lipid extracts.

The FAME were prepared from the crude lipid extracts as described by Carreau and Dubacq (1978). Samples were analyzed by GC-flame ionization detection (GC-FID; 7890B; Agilent Technologies, Santa Clara, CA) with an SGE BPX70 capillary column (60 $\mathrm{m} \times 0.25 \mathrm{~mm}$ i.d., $0.25 \mu \mathrm{m}$; Thermo Fisher Scientific). Helium was used as the carrier gas with a split ratio of 100:1. The flow rate was $1.0 \mathrm{~mL} / \mathrm{min}$. The injector and detector temperatures were both set to $260^{\circ} \mathrm{C}$. The oven temperature was held at $45^{\circ} \mathrm{C}$ for 4 min, increased by $15^{\circ} \mathrm{C} / \mathrm{min}$ to $165^{\circ} \mathrm{C}$ (held for $1 \mathrm{~min}$ ), followed by an increase of $2^{\circ} \mathrm{C} / \mathrm{min}$ to $225^{\circ} \mathrm{C}$ (held for $20 \mathrm{~min}$ ). Individual peaks of FAME were identified by comparison with the FAME standards. Methyl tricosanoate was used as an internal standard to normalize the peak areas of different fatty acid species to correct the differences in response factors. Fatty acids were expressed as the percentages of individual fatty acids relative to the total. Those FAME not available in the mix FAME standard (GLC-714) were identified by elution order according to our previous study (Teng et al., 2017).

\section{vBCFA Analysis by GC-MS}

Liquid sheep milk samples were lyophilized over $2 \mathrm{~d}$ at $-45^{\circ} \mathrm{C}$, and $0.8 \mathrm{~g}$ of the lyophilized milk was extracted by the azeotropic mixture of cyclohexane/ethyl acetate (46/54, vol/vol) using an accelerated solvent extraction system (ASE 350; Dionex; Kaffarnik et al., 2014; Teng et al., 2018). Two extraction cycles were performed. The extraction temperature and pressure were set to $125^{\circ} \mathrm{C}$ and $10 \mathrm{MPa}$, respectively. The extracts were quantitatively transferred into $10-\mathrm{mL}$ tubes, and the solvent was evaporated under reduced pressure. The total fat content was then determined gravimetrically. The extracts were made up to $1.0 \mathrm{~mL}$ with cyclohexane/ethyl acetate (46/54, vol/vol).

To determine the total amount of vBCFA (including esterified form and free-form vBCFA), $0.5 \mathrm{~mL}$ of the milk fat extract was transferred to a $10-\mathrm{mL}$ tube with a screw cap. Sulfuric acid in methanol $(1 \%, 3 \mathrm{~mL})$ was added to the milk fat extract and the mixture was heated at $80^{\circ} \mathrm{C}$ for $2 \mathrm{~h}$. After cooling, $1 \mathrm{~mL}$ each of saturated sodium chloride solution, distilled water and $n$ hexane were added. After vigorous shaking, the organic phase (which contained the FAME) was separated for subsequent GC-MS analysis. To determine the amount of the esterified form vBCFA only, another $0.5 \mathrm{~mL}$ of the milk fat extract was used for methylation using a different method. First, $n$-hexane $(1 \mathrm{~mL})$ was added to the extract, followed by $100 \mu \mathrm{L}$ of sodium methoxide (0.5 $M$ in methanol). The mixture was then vortexed 
4 to 5 times during a 10-min period. Acetic acid (5 $\mu \mathrm{L})$ was added to neutralize the sodium methoxide. After vortexing, anhydrous calcium chloride was added, and the sample was incubated at room temperature for $60 \mathrm{~min}$. The sample was then centrifuged at $10,000 \times$ $g$ at $4^{\circ} \mathrm{C}$ for $30 \mathrm{~min}$, and the $n$-hexane phase (which contained the FAME) was then transferred to a 1.5$\mathrm{mL}$ vial for $\mathrm{GC} / \mathrm{MS}$ analysis. The amounts of free-form vBCFA were calculated by subtracting the amounts of esterified vBCFA from the total amounts of vBCFA.

\section{OAV and Flavor Values}

Sensory thresholds of 0.0057 and $0.00043 \mu \mathrm{g} / \mathrm{g}$, respectively, have been reported for 4-Me-8:0 and 4-Et8:0 when dissolved in a buffered solution (Salles et al., 2002 ), and a sensory threshold of $2.24 \mu \mathrm{g} / \mathrm{g}$ for $4-\mathrm{Me}-$ 9:0 (Salvatore et al., 2007). These values, together with the concentrations of vBCFA in milk $(\mu \mathrm{g} / \mathrm{g}$ of milk, Supplemental Tables S2 and S3; https://doi.org/10 $.3168 /$ jds.2019-17192), were used to estimate the OAV of vBCFA in milk and the FV of vBCFA in milk products (e.g., cheese, yogurt, or milk powder). The OAV of each vBCFA in milk were calculated as the ratio of its free-form concentration (fresh weight, $\mu \mathrm{g} / \mathrm{g}$ of milk) to its sensory threshold. The FV were calculated as the ratio of the total amount of each vBCFA (fresh weight, $\mu \mathrm{g} / \mathrm{g}$ of milk) to its sensory threshold.

\section{Statistical Analysis}

Because this was a case study, descriptive statistics are used to describe the data. Comparisons between groups do not necessarily reflect true treatment differences, because the treatments were not independently replicated. In addition, any effects of genetics, age, lactation stage, feed composition, lambing date, or the environment in the housing barn or outdoors were confounding factors. Therefore, the results obtained from this study were descriptive rather than definitive, because of the limitations of the experimental design.

In addition to the major confounding factors, some random effects such as the order of ewes during automatic milking and the random milking parlors for ewes in each group occurred in this study. Therefore, we investigated the effects of different factors on vBCFA levels using the linear mixed model fitted by REML using R 3.5.4 (http://CRAN.R-project.org/; Duchateau et al., 1998; Viechtbauer, 2005). The REML model is often used in the complicated context of mixed models and is unbiased for the random effects (Duchateau et al., 1998; Viechtbauer, 2005). Samples collected at transition (wk 0) were removed in this model. Treatment group (i.e., fully housed/mid-lactation or pasture- grazed/late lactation), DIM, sampling date, and daily milk yield were highly correlated. Therefore, they are reported as descriptors of the conditions, rather than being compared between the treatment groups. A mixed effects model was fitted for each logged response (i.e., total and free-form amounts of 4-Me-8:0, 4-Et-8:0, and 4-Me-9:0) with collection time as the random effect. Normally, treatment group would also be a random effect, but because it was confounded with many variables of interest, we left it in the model as a fixed effect. Because the fully housed/mid-lactation ewes were not fed grazed forage and the pasture-grazed/late-lactation ewes had almost no lucerne silage intake (Supplemental Table S1; https://doi.org/10.3168/jds.2019-17192), the proportions of grazed forage and lucerne silage in the diet were removed from the model. Explanatory variables included in the model were treatment group, DIM, proportion of grass silage in the diet, proportion of barley in the diet, and proportion of soy meal in the diet. The $P$-values from the 6 models were adjusted to account for multiple comparisons (Benjamini and Hochberg, 1995). This inflated the $P$-values to reduce the risk of false positives when making many comparisons (false positives become much more common as the number of tests increases). We used this approach to provide a guide to variables that may be related to the responses measured, rather than as a definitive reason for the responses because of the limitations of the experimental design.

Data for individual daily milk yield were quality checked using R 3.5.4 (http://CRAN.R-project.org/), removing any outliers (1.5 times the interquartile range) by first making box plots. Means were then calculated after the removal of outliers. Differences in milk composition and vBCFA levels in milk between the 2 groups were investigated using the Tukey honestly significant difference test in $\mathrm{R}$ 3.5.4. Statistical significance was indicated by $P<0.05$, and highly significant differences were indicated by $P<0.01$.

\section{RESULTS AND DISCUSSION}

\section{Changes in Daily Milk Yield, BCS, and Live Weight}

Means for daily milk yield, live weight, and BCS for each group of ewes are summarized in Table 1. At transition (wk 0), the daily milk yield of the fully housed/ mid-lactation ewes $(0.72 \mathrm{~L} /$ ewe per day) was numerically greater than that of the pasture-grazed/late-lactation ewes $(0.58 \mathrm{~L} /$ ewe per day) with similar DMI, but not statistically different $(P>0.05)$. On average, the daily milk yield decreased by approximately $20 \%$ in wk 1 for both groups (to 0.56 and $0.46 \mathrm{~L} /$ ewe per day, respectively, Table 1), and then continued to decline 
Table 1. Daily milk yield and animal condition

\begin{tabular}{|c|c|c|c|c|c|c|}
\hline Group and week & $\begin{array}{l}\text { Date } \\
(\mathrm{mo} / \mathrm{d} / \mathrm{yr})\end{array}$ & $\begin{array}{c}\text { DMI } \\
(\mathrm{kg} / \mathrm{d} \text { per ewe })\end{array}$ & $\begin{array}{l}\text { Daily milk yield }{ }^{1} \\
\text { (L/d per ewe) }\end{array}$ & $\begin{array}{l}\text { Live weight }{ }^{1} \\
(\mathrm{~kg})\end{array}$ & $\mathrm{BCS}^{1}$ & $\begin{array}{l}\mathrm{ADG}^{1} \\
(\mathrm{~g} / \mathrm{d})\end{array}$ \\
\hline \multicolumn{7}{|c|}{ Fully housed/mid-lactation } \\
\hline 0 & $12 / 22 / 2016$ & 1.01 & $0.72 \pm 0.40$ & $\mathrm{ND}^{2}$ & ND & 98 \\
\hline 2 & $1 / 19 / 2017$ & $1.51 \pm 0.37$ & $0.52 \pm 0.29$ & ND & ND & \\
\hline 3 & $1 / 26 / 2017$ & $1.80 \pm 0.12$ & $0.47 \pm 0.15^{*}$ & ND & ND & \\
\hline 4 & $2 / 2 / 2017$ & $1.80 \pm 0.18$ & $0.49 \pm 0.17$ & ND & ND & \\
\hline \multicolumn{7}{|c|}{ Pasture grazed/late lactation } \\
\hline 0 & $12 / 22 / 2016$ & 0.94 & $0.58 \pm 0.34$ & ND & ND & 0 \\
\hline 1 & $1 / 12 / 2017$ & $1.25 \pm 0.37$ & $0.46 \pm 0.25$ & $72.7 \pm 0.6^{*}$ & $4.2 \pm 0.02$ & \\
\hline 2 & $1 / 19 / 2017$ & $1.53 \pm 0.36$ & $0.46 \pm 0.27$ & ND & ND & \\
\hline 3 & $1 / 26 / 2017$ & $1.62 \pm 0.53$ & $0.38 \pm 0.13^{*}$ & ND & ND & \\
\hline 4 & $2 / 2 / 2017$ & $1.78 \pm 0.20$ & $0.43 \pm 0.12$ & ND & ND & \\
\hline
\end{tabular}

${ }^{1}$ Modified from Bliss et al. (2018); data were quality checked using R 3.5.4 (http://CRAN.R-project.org/), any outliers (1.5 times the interquartile range) were removed, and data are presented as mean $\pm \mathrm{SD}$.

${ }^{2} \mathrm{ND}=$ not determined.

$* P<0.05$ for the significant difference between fully housed/mid-lactation and pasture-grazed/late-lactation groups.

to the end of the trial. Daily milk yield had decreased by approximately $44 \%$ by wk 7 (to 0.30 and $0.27 \mathrm{~L} /$ ewe per day, respectively) compared with wk 1 in both groups. However, the daily milk yields from wk 1 to wk 7 were not significantly different $(P>0.05)$ between groups because of large variations between individual ewes. Live weights for fully housed/mid-lactation ewes were significantly lower than for pasture-grazed/latelactation ewes at the beginning of the trial $(70.9 \mathrm{~kg}$ vs. $72.7 \mathrm{~kg}$, Table 1). The fully housed/mid-lactation ewes had an ADG of $98 \mathrm{~g} / \mathrm{d}$ during the trial, whereas ewes in the pasture-grazed/late-lactation group did not gain weight under similar DMI. As a consequence, the live weight of the fully housed/mid-lactation ewes was significantly greater than that of the pasture-grazed/ late-lactation ewes at the end of the trial (75.5 vs. 72.4 $\mathrm{kg}$, Table 1). The BCS of ewes were comparable at both the beginning and the end of the trial (Table 1).

A similar decrease in daily milk yield was observed in other studies, indicating a difference of 40 to $60 \%$ between late-lactation and mid-lactation East Friesian cross-bred ewes (Kuchtík et al., 2008; Mioč et al., 2009; Novotná et al., 2009). This might be attributed to a reduction in milk synthesis resulting from lower feed intake in heat-stressed ewes and the advancement of lactation (Oravcová et al., 2006; Sevi and Caroprese, 2012). The smaller decrease in the current study may be due to the supplements fed to the ewes to mitigate energy deficiency under hot and dry climatic conditions. It was unlikely that the greater ADG of the fully housed/mid-lactation ewes was caused by lower energy expenditure, because Bliss et al., (2018) calculated that the energy requirement of housed ewes was only 0.3 MJ of ME/d lower than that of grazed ewes. The higher digestibility of the TMR compared to grazed forage consumed by the pasture-grazed/late-lactation ewes may explain some of the observed differences (Nasrollahi et al., 2017).

\section{Changes in Milk Composition}

The milk composition was not significantly different between the 2 groups at transition (wk 0). During the trial (wk 1-7), total solids, fat content, and protein content increased over time (Figure 1a-c). Total solids were similar in milk from the 2 groups at the end of the trial (Figure 1a), but we observed differences between groups in the proportions of fat, protein, and lactose making up the milk solids, particularly toward the end of the trial (Figure 1b-d).

The observed increases in total solids and fat and protein content in milk derived from the fully housed/ mid-lactation ewes $(0.9$ to $2.8 \%, 1.1$ to $2.3 \%$, and -0.3 to $1.4 \%$, respectively) and pasture-grazed/latelactation ewes (0.3 to $2.7 \%, 0.5$ to $2.7 \%$, and 0 to $1.0 \%$, respectively) with the advancement of lactation stage were within the ranges of previous studies $(0.8$ to $8.0 \%$, 0.2 to $6.0 \%$, and 0.5 to $3.3 \%$, respectively; Caja and Bocquier, 2000; Pavić et al., 2002; Sahan et al., 2005; Kuchtík et al., 2008; Novotná et al., 2009). The lactose content was relatively constant throughout the study, in agreement with reports in the literature (Pavić et al., 
2002; Novotná et al., 2009; Bliss et al., 2018; Kotsampasi et al., 2018).

The differences in milk composition between the 2 groups at the end of the trial-particularly the lower fat content in milk from the fully housed/mid-lactation ewes in wk 6 and 7 compared with that from the pasture-grazed/late-lactation ewes - could have been an effect of the physicochemical properties of the feed. The provision of concentrates and smaller proportion of forage in the diet may tend to decrease acetate and butyrate formation (Caja and Bocquier, 2000). These VFA are the main precursors of the fatty acids synthesized in the mammary gland, and if their production is inhibited, animals' milk will have a lower fat content
(Caja and Bocquier, 2000; Morand-Fehr et al., 2007; Sanz Sampelayo et al., 2007; Haenlein and Wendorff, 2008).

\section{Changes in Fatty Acid Composition}

Although the total fat content in milk from the 2 groups was comparable at transition (wk 0, Figure 1b), the milk fatty acid composition was significantly different at this time point. Milk from the fully housed/ mid-lactation ewes had higher proportions of SFA (79.6\%), short-chain fatty acids (SCFA; $7.13 \%$ ), and medium-chain fatty acids (MCFA; 19.9\%) compared with milk from the pasture-grazed/late-lactation ewes

$\longrightarrow$ - Fully housed/mid-lactation

- - - - Pasture-grazed/late-lactation
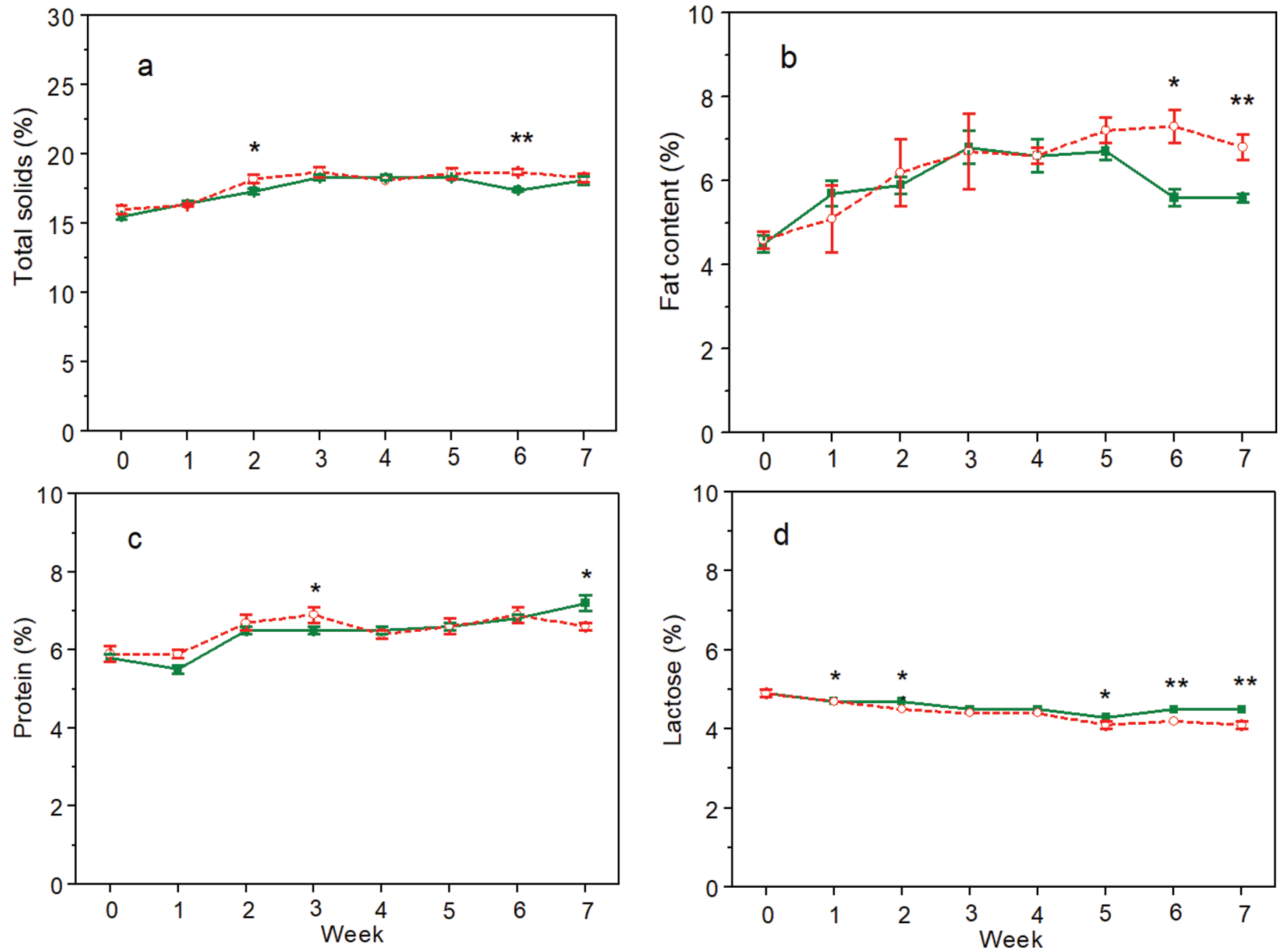

Figure 1. Milk composition at transition (wk 0) and during the trial period (wk 1-7): (a) total solids content; (b) fat content; (c) protein content; and (d) lactose content. Data were compared using Tukey's honestly significant difference test using R 3.5.4 (http://CRAN.R-project $.0 \mathrm{~g} /)$. ${ }^{*} P<0.05 ;{ }^{* *} P<0.01$. Error bars indicate SD. 
(72.7, 6.93, and $16.2 \%$, respectively for SFA, SCFA, and MCFA; Table 2). Conversely, the proportions of MUFA, PUFA, long-chain fatty acids (LCFA), and odd- and branched- chain fatty acids (OBCFA) were lower in milk from fully housed/mid-lactation ewes $(14.0,3.05,70.7$, and $3.39 \%$, respectively, Table 2$)$ than in milk from pasture-grazed/late-lactation ewes (19.6, $4.04,74.1$, and $3.65 \%$, respectively, Table 2$)$.

We observed remarkable changes $(P<0.05)$ in fatty acid composition in milk collected in wk 1 compared with wk 0 for both groups. The proportions of SFA, SCFA, and MCFA decreased by $7.50,0.90$, and $6.60 \%$, respectively, in milk from fully housed/mid-lactation ewes, and by $3.40,1.09$, and $3.60 \%$, respectively, in milk from pasture-grazed/late-lactation ewes (Table 2). Conversely, the proportions of MUFA, LCFA, and OBCFA increased by $6.30,6.70$, and $0.39 \%$, respectively, in milk from fully housed/mid-lactation ewes, although the increase was slightly less in milk from pasture-grazed/ late-lactation ewes $(3.20,4.40$, and $0.36 \%$, respectively, Table 2). Changes in the proportions of PUFA were opposite in the milk from the 2 groups (Table 2).

Although we found some variations in the fatty acid composition of milk from the 2 groups during the trial period (wk 1-7), the fatty acid proportions of milk from the fully housed/mid-lactation ewes were not significantly different $(P>0.05)$ in wk 7 compared to wk 1 (Table 2). As a result, the milk from fully housed/mid-lactation ewes contained higher proportions of SFA (68.7-72.7\%), SCFA (4.81-6.23\%), and MCFA (10.0-14.2\%) than milk from pasture-grazed/ late-lactation ewes $(63.6-69.3 \%, 4.15-5.84 \%$, and 6.69-12.6\%, respectively, Table 2) throughout the trial. Conversely, the proportions of MUFA, PUFA, LCFA, and OBCFA were lower in milk from fully housed/midlactation ewes $(19.4-23.2 \%, 3.26-4.03 \%, 77.4-82.2 \%$, and $3.65-4.10 \%$, respectively, Table 2) than in milk from pasture-grazed/late-lactation ewes (22.8-27.6\%, $3.92-4.47 \%, 78.5-85.2 \%$, and $4.01-4.77 \%$, respectively, Table 2).

Higher proportions of PUFA [i.e., linoleic acid (C18:2n-6), CLA, and $\alpha$-linolenic acid (C18:3n-3); Supplemental Table S4; https://doi.org/10.3168/jds.2019 -17192] were found in milk from pasture-grazed/latelactation ewes compared with milk from fully housed/ mid-lactation ewes at transition (wk 0) and during the trial period (wk 1-7). This was likely due to the high grazed forage intake of the pasture-grazed/latelactation ewes (Supplemental Table S1). Many studies have reported that grass-based feeding enhances PUFA in milk, particularly $\alpha$-linolenic acid (Chilliard et al., 2000; Dewhurst et al., 2006; Hur et al., 2017; Gebreyowhans et al., 2019). The concentration of these PUFA is highly associated with feed source, and $\alpha$-linolenic acid, linoleic acid, and oleic acid (C18:1 cis-9) were found in proportions of 53,13 , and $10 \%$, respectively, of the total fatty acids in pasture grasses (Watkins et al., 2013). Additionally, CLA can be synthesized through biohydrogenation of linoleic acid by ruminal microbiota, and grass-based feeding not only provides more linoleic acid but also enhances the growth of specific ruminal microbiota that are responsible for the synthesis of CLA in animals (Hur et al., 2017). However, the reason for the increase of $\alpha$-linolenic acid in milk fat by grass-based feeding is not yet fully understood (Destaillats et al., 2005; Gebreyowhans et al., 2019).

\section{Changes in Levels of VBCFA}

Concentrations of total and free-form vBCFA were measured in milk from the 2 groups, both at transition and during the trial period (Figure 2). At transition (wk 0), the concentration of total 4-Me-8:0 and 4-Me9:0 were comparable in milk from the 2 groups (wk 0 , Figure 2a,b). However, the concentration of total 4-Et8:0 was much lower in milk from fully housed/mid-lactation ewes compared with milk from pasture-grazed/ late-lactation ewes (wk 0, Figure 2c). In contrast, concentrations of free-form 4-Me-8:0 and 4-Me-9:0 in milk from fully housed/mid-lactation ewes were about half of that in milk from pasture-grazed/late-lactation ewes (wk 0, Figure 2d,e). The concentrations of free-form 4-Et-8:0 were not significantly different $(P>0.05)$ in milk from the 2 groups (wk 0, Figure 2f).

Compared with the transition (wk 0), in wk 1 the concentration of total 4-Me-8:0 in milk from both groups decreased by half (Figure 2a). Decreases in the concentration of total 4-Me-9:0 in wk 1 were even larger $(\sim 70 \%$, Figure $2 \mathrm{~b})$. However, the concentration of total 4-Et-8:0 increased in wk 1 in the fully housed/midlactation group and declined in the pasture-grazed/ late-lactation group (Figure 2c). Similar changes were observed in the concentrations of free-form vBCFA in wk 1 compared with wk 0 (Figure 2d-f).

During the trial period (wk 1-7), vBCFA concentrations varied differently between 2 groups (Figure 2). For the fully housed/mid-lactation ewes, the concentration of total 4-Me-8:0 changed little from wk 1 to wk $5(122.9-142.5 \mu \mathrm{g} / \mathrm{g}$ of fat, Figure $2 \mathrm{a})$, then increased in wk $6(240.0 \mu \mathrm{g} / \mathrm{g}$ of fat, Figure $2 \mathrm{a})$, and finally decreased slightly in wk $7(205.9 \mu \mathrm{g} / \mathrm{g}$ of fat, Figure $2 \mathrm{a})$. The changes in concentration of total 4-Me-9:0 followed the same trend, with the highest concentration also observed in wk $6(4.28 \mu \mathrm{g} / \mathrm{g}$ of fat, Figure $2 \mathrm{~b})$ for the fully housed/mid-lactation group. We observed small changes in the concentration of total 4-Et-8:0 throughout the trial, except in wk 2, where the concentration was about half of that observed in other weeks for the 
Teng et al.: LEVELS OF VOLATILE BRANCHED CHAIN FATTY ACIDS IN SHEEP MILK

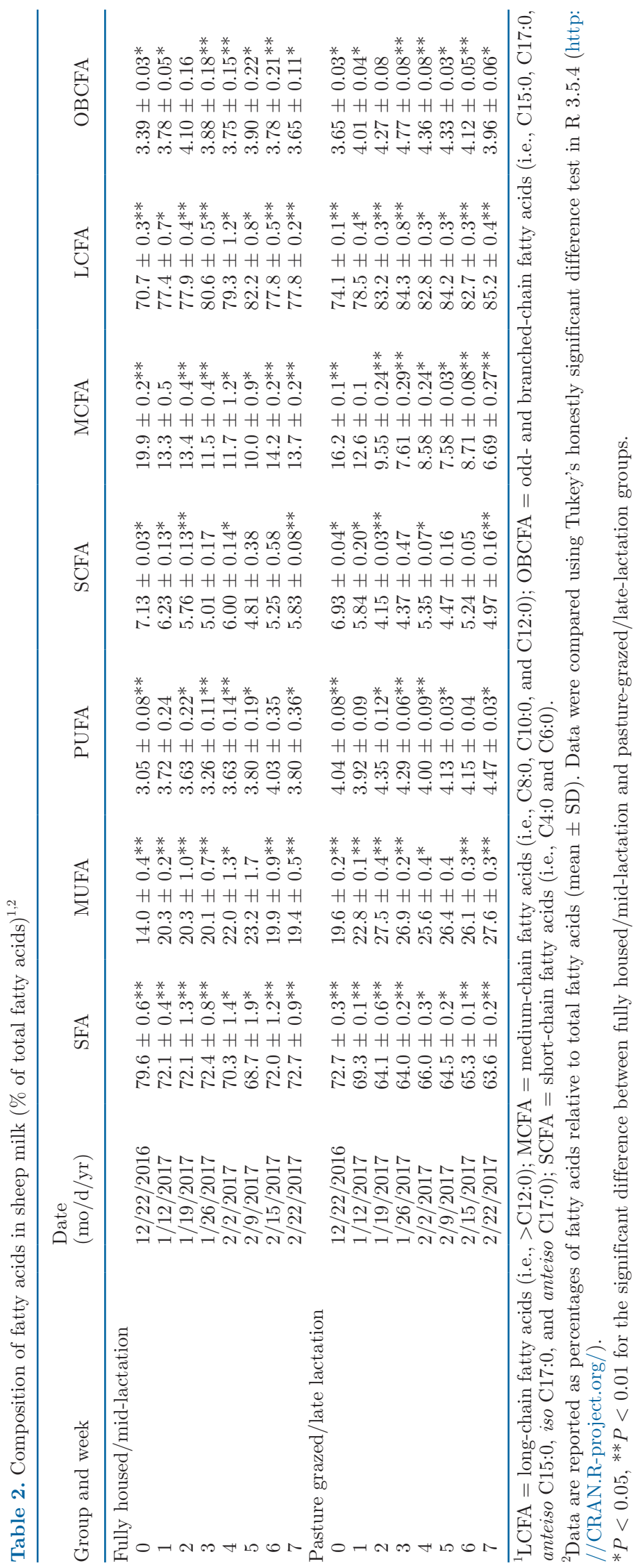


- Fully housed/mid-lactation

- - - - Pasture-grazed/late-lactation
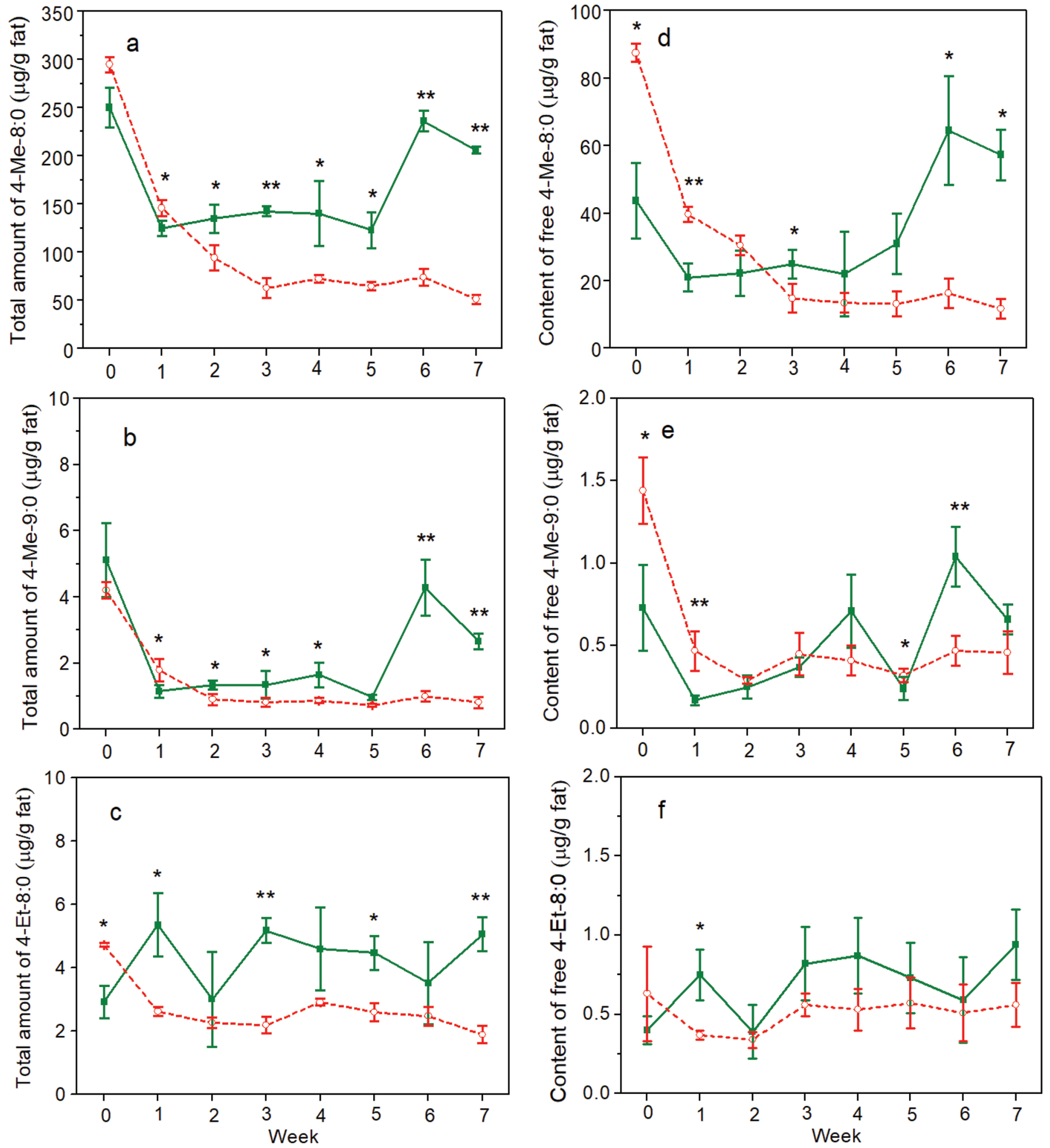

Figure 2. Levels of volatile 4-alkyl branched-chain fatty acids in sheep milk ( $\mu \mathrm{g} / \mathrm{g}$ of fat): (a, b, c) total concentrations of 4-methyloctanoic acid (4-Me-8:0), 4-methylnonanoic acid (4-Me-9:0), and 4-ethyloctanoic acid (4-Et-8:0), respectively; (d, e, f) concentrations of free-form 4-Me8:0, 4-Me-9:0, and 4-Et-8:0, respectively. Data were compared using Tukey's honestly significant difference test using R 3.5.4 (http://CRAN.R -project.org/). ${ }^{*} P<0.05 ;{ }^{*} P<0.01$. Error bars indicate SD. 
fully housed/mid-lactation group (2.99 vs. $3.51-5.35$ $\mu \mathrm{g} / \mathrm{g}$ of fat, Figure 2c). The concentrations of free-form vBCFA followed the same trends as total concentrations, with the highest concentration of 4-Me-8:0 and 4-Me-9:0 also found in wk $6(64.5$ and $1.04 \mu \mathrm{g} / \mathrm{g}$ of fat, respectively, Figure 2d,e) and the lowest concentration of free-form 4-Et-8:0 observed in wk $2(0.39 \mu \mathrm{g} / \mathrm{g}$ of fat, Figure 2f). For the pasture-grazed/late-lactation ewes, the concentration of total 4-Me-8:0 (145.8-51.1 $\mu \mathrm{g} / \mathrm{g}$ of fat, Figure 2a) and 4-Me-9:0 (1.79-0.73 $\mu \mathrm{g} / \mathrm{g}$ of fat, Figure $2 \mathrm{~b}$ ) in milk continued to decrease as the trial proceeded, and they were significantly $(P<0.05)$ lower than the concentrations in milk from the fully housed/mid-lactation ewes at sampling wk 2 to 7 (Figure 2a,b, except for total 4-Me-9:0 concentration in wk $5)$. The concentration of total 4-Et-8:0 differed little in the pasture-grazed/late-lactation group during the trial period $(1.88-2.90 \mu \mathrm{g} / \mathrm{g}$ of fat, Figure 2c), with lower values than those from the fully housed/mid-lactation ewes at sampling wk 1 to 7 (Figure 2c). Concentrations of free-form vBCFA changed in line with total amounts; lower concentrations of free-form 4-Me-8:0 were found at sampling wk 3 to 7 compared with those in milk from fully housed/mid-lactation ewes (Figure 2d). Concentrations of free-form 4-Me-9:0 (except for wk 1, 5, and 6) and 4-Et-8:0 (except for wk 1) were not significantly different from those in milk from fully housed/mid-lactation ewes (Figure 2e,f).

The differences in the concentrations of total and free-form vBCFA in milk from the 2 groups at transition (wk 0, Figure 2) could have been due to the different lactation stages. The majority (90\%) of the fully housed ewes were in mid lactation when the trial started, and more than half $(57 \%)$ of the pasture-grazed ewes were in late lactation. However, if adjusted for DIM, wk 0 to 4 for the pasture-grazed/late-lactation ewes (121-149 d) were equivalent to wk 3 to 7 for the fully housed/ mid-lactation ewes $(123-150 \mathrm{~d})$. This suggests that the results from this study indicated that the concentrations of vBCFA were more influenced by diet than by stage of lactation during the trial period (wk 1-7). Higher lipase activity found in late lactation (Haenlein and Wendorff, 2008) may contribute to an increase in the concentrations of free-form vBCFA. The data from the current study were in agreement with observations from our previous work, in which the concentrations of free-form 4-Me-8:0, 4-Me-9:0, and 4-Et-8:0 increased by 61,12 , and $73 \%$ respectively, in late lactation compared with the average concentrations throughout the lactation season (Teng et al., 2018). However, these results should be interpreted with the difference in lactation stage between the groups in mind, and were indicative of the conditions rather than predictive or conclusive.
The reduction $(P<0.05)$ of vBCFA levels in milk from both groups (except for concentrations of total and free-form 4-Et-8:0 in milk from the fully housed/ mid-lactation ewes, Figure 2) occurred at the beginning of the trial (wk 1, January 12) compared with the levels at transition (wk 0, December 22). This could have been an effect of seasonal changes, because we found similar decreases of vBCFA concentrations in milk from pasture-fed ewes collected in January compared with milk collected in December in our previous work (19, 16 , and $11 \%$ on average for $4-\mathrm{Me}-8: 0,4-\mathrm{Me}-9: 0$, and 4-Et-8:0, respectively; Teng et al., 2018). However, the decreases observed in the present study $(\sim 50 \%)$ could also be attributed to the variations in composition of forage, the supplements fed, or the transition process itself. More work is required for a deeper understanding of the influence of these factors on vBCFA concentrations.

The differences in trends of $\mathrm{vBCFA}$ concentrations (both total and free-form) in milk from the 2 groups during the trial period (wk 1-7)-particularly the increases of 4-Me-8:0 and 4-Me-9:0 in milk from the fully housed/mid-lactation ewes in wk 6-may have been reflective of a combination of factors in this study (e.g., lactation stage and feed composition). Therefore, we estimated factors affecting vBCFA levels using the linear mixed model fitted by REML. However, only an increase in the concentration of free-form 4-Et-8:0 in milk from the 2 groups was positively correlated with the proportion of soy meal $(P<0.05)$ fed to ewes, and was negatively correlated $(P<0.05)$ with the proportion of barley. The underlying reasons for these opposing trends are not clear. Therefore, studies that separate the confounding factors (e.g., genetics, age, lactation stage, or feed composition) in this study are required to explore this further.

Concentrations of total vBCFA were greater in milk from fully housed/mid-lactation ewes at sampling wk 2-7 compared with milk from pasture-grazed/latelactation ewes (Figure 2a-c), as were the free-form concentrations of 4-Me-8:0 and 4-Me-9:0, particularly at the end of the trial (wk 6 and 7, Figure 2d,e). This may have been related to the large proportions of lucerne silage fed to the fully housed/mid-lactation ewes (Supplemental Table S1; https://doi.org/10.3168/jds .2019-17192). High levels of lucerne in the diet of ewes may decrease the ratio of acetate/propionate in the rumen, and as a result more vBCFA may be synthesized because of the increase in propionate concentration (Ellison et al., 2017). Several studies have found that greater levels of vBCFA in meat from sheep fed with supplements (e.g., lucerne, maize, or barely) compared with pasture-fed sheep. For example, greater levels of 
4-Me-8:0 and 4-Me-9:0 were measured in meat from New Zealand lambs fed a maize- or lucerne-based concentrate diet than in meat from pasture-fed lambs (Young et al., 2003). Concentrations of monomethylvBCFA (e.g., 4-Me-8:0 and 4-Me-9:0) were higher in the adipose tissue of barley-fed sheep compared to grass-fed sheep (Duncan and Garton, 1978). Greater concentrations of 4-Et-8:0 $(131 \mu \mathrm{g} / \mathrm{g})$ were observed in the subcutaneous fat of lucerne-fed lambs than in ryegrass-fed lambs, whereas the levels of 4-Me-8:0 (267 and $220 \mu \mathrm{g} / \mathrm{g}$, respectively) and 4-Me-9:0 (35.3 and $35.1 \mu \mathrm{g} / \mathrm{g}$, respectively) were not significantly different (Frank et al., 2016).

\section{Changes in OAV and Flavor Values}

The OAV derived from the concentrations of freeform vBCFA in milk $(\mu \mathrm{g} / \mathrm{g}$ of milk, Supplemental Table S2; https://doi.org/10.3168/jds.2019-17192) are summarized in Figure 3a. The OAV in milk from the fully housed/mid-lactation ewes were about half of that from pasture-grazed/late-lactation ewes at transition (wk 0, Figure 3a), although this difference was not statistically significant because of the large variation. The OAV in milk from fully housed/mid-lactation ewes increased considerably in wk 1 , and were significantly different from the overall OAV in milk from the pasture-grazed/ late-lactation ewes (Figure 3a). During the trial period (wk 1-7), the overall OAV in milk from the 2 groups were not significantly different, except at the beginning and the end of the trial (wk 1 and 7, Figure 3a). The
OAV changed little for both groups during the trial period. The values in wk 7 (179.2 and 102.3, respectively, for the fully housed/mid-lactation and the pasturegrazed/late-lactation ewes) were not significantly different from that in wk 1 (122.1 and 79.4, respectively, Figure 3a) for both groups.

To estimate the flavor intensity of sheep milk products, FV were derived from the concentrations of the total amounts of vBCFA in milk $(\mu \mathrm{g} / \mathrm{g}$ of milk, Supplemental Table S3; https://doi.org/10.3168/ jds.2019-17192) and are presented in Figure 3b. The overall FV were significantly lower in milk from fully housed/mid-lactation ewes than in milk from pasturegrazed/late-lactation ewes at transition (wk 0, Figure $3 \mathrm{~b}$ ). During the trial period (wk 1-7), the FV varied between 609.2 and 1,068.3 in milk from fully housed/ mid-lactation ewes, significantly higher than that from pasture-grazed/late-lactation ewes at wk 3, 5, and 7 (Figure $3 \mathrm{~b}$ ). At the end of the trial (wk 7), the FV of milk from pasture-grazed/late-lactation ewes were significantly different $(P>0.05)$ from those in wk 1 , and $\mathrm{FV}$ in milk from fully housed/mid-lactation ewes were not significantly different from those in wk 1 (Figure $3 \mathrm{~b})$.

Because its sensory threshold is over 100 times lower than that of 4-Me-8:0 and 4-Me-9:0, 4-Et-8:0 plays the most important role in the sheepy flavor of sheep milk (Kaffarnik et al., 2014; Teng et al., 2018). Indeed, 4-Et8:0 contributed 53.8 to $4.7 \%$ and 47.5 to $85.6 \%$, respectively, to the overall OAV of milk from the fully housed/ mid-lactation and pasture-grazed/late-lactation ewes in

\section{- Fully housed/mid-lactation \\ - - - - Pasture-grazed/late-lactation}
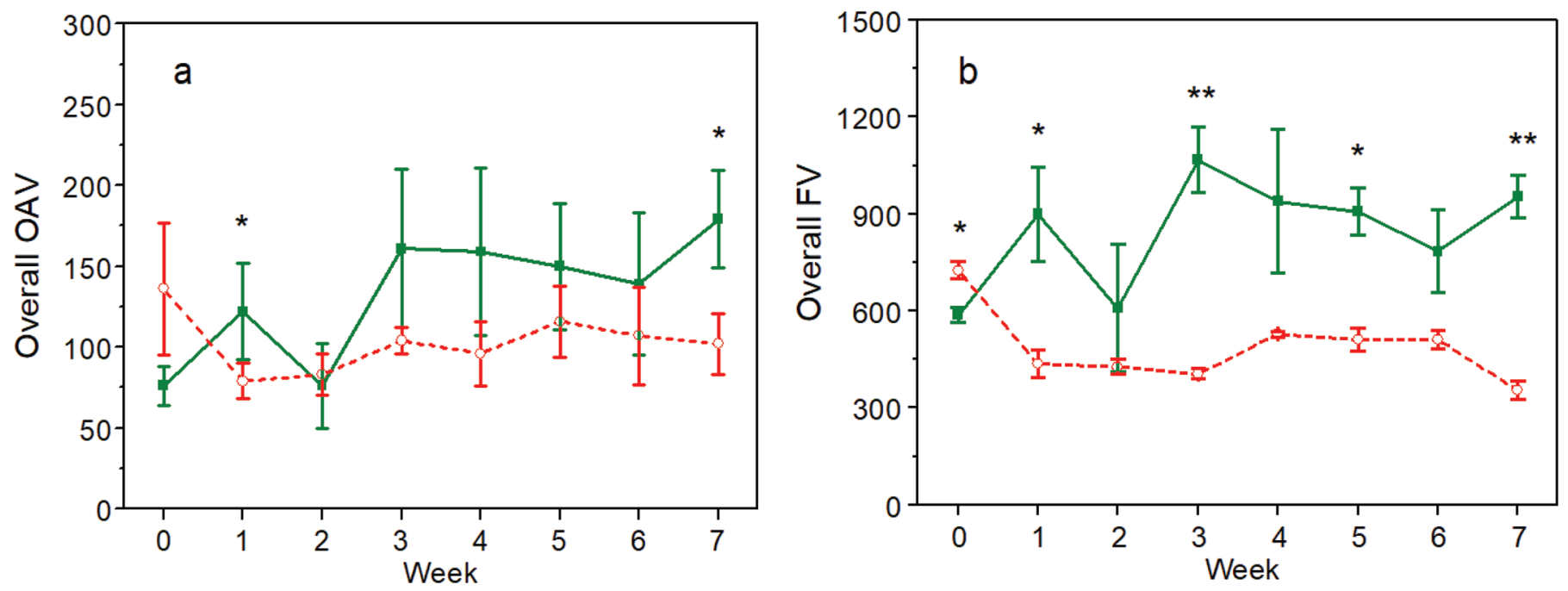

Figure 3. Overall (a) odor activity values (OAV), and (b) flavor values (FV) of sheep milk. Data were compared using Tukey's honestly significant difference test using R 3.5.4 (http://CRAN.R-project.org/). ${ }^{*} P<0.05 ;{ }^{* *} P<0.01$. Error bars indicate SD. 
the present study. Odor activity values changed in line with the levels of free-form 4-Et-8:0 in the 2 groups (Figure $2 \mathrm{f}$ and Figure $3 \mathrm{a}$ ).

In addition, 4-Et-8:0 contributed more to the overall FV (60.3-84.7\% and $67.9-84.2 \%$ for the fully housed/ mid-lactation and pasture-grazed/late-lactation groups, respectively) than to the overall $\mathrm{OAV}$, so $\mathrm{FV}$ changed in accordance with the total amounts of 4-Et-8:0 (Figure $2 \mathrm{c}$ and Figure $3 \mathrm{~b}$ ). The higher FV in milk from the fully housed/mid-lactation ewes than those from the pasturegrazed/late-lactation ewes were predominantly due to higher total amounts of 4-Et-8:0 (Figure 2c). Flavor values can be used to estimate the flavor intensity of milk products such as cheese, yogurt, or milk powder, because the esterified form of vBCFA can be hydrolyzed during processing (e.g., fermentation, hydrolysis), causing a release of free-form vBCFA. In our previous study, an increase of free-form vBCFA was observed after spray-drying, compared with the unprocessed milk (Teng et al., 2018). The higher FV of sheep milk from the fully housed/mid-lactation ewes will likely produce sheep milk products with a stronger sheepy flavor than those from pasture-grazed/late-lactation ewes.

The differences in OAV and FV of milk samples between the 2 groups or different time points during the trial period might be perceived by customers according to the results of our previous sensory study: 3 bulk milk samples collected from pasture-fed ewes at early, mid- and late lactation were investigated. The overall OAV and FV of the milk samples differed by lactation stage: $17 \pm 10$ and $309 \pm 7$ for early lactation, $78 \pm$ 23 and $638 \pm 20$ for mid-lactation, and $393 \pm 45$ and $1735 \pm 135$ for late lactation (data not published). The sensory score of the sheepy flavor also varied between the 3 milk samples: $26 \pm 25,43 \pm 36$, and $60 \pm 38$ for early, mid-, and late lactation, respectively (data not published).

\section{CONCLUSIONS}

Factors influencing the total amounts and levels of free-form vBCFA in New Zealand sheep milk were investigated in this study. Although several confounding factors were present (i.e., age, lactation stage, feed composition, and environment), significant effects of overall management on the concentrations of vBCFA in sheep milk were still observed. Significantly higher concentrations of 4-Me-8:0 and 4-Me-9:0 were found in milk from fully housed/mid-lactation ewes compared with milk from pasture-grazed/late-lactation ewes. Concentrations of 4-Et-8:0 in milk from the 2 groups were comparable. Concentrations of 4-Me-8:0 and 4-Me9:0 were likely associated with lactation stage and the proportion of lucerne silage fed to the ewes. Increases of free-form 4-Et-8:0 concentrations were associated with an increase in the proportion of soy meal fed to ewes, and with a decrease in the proportion of barley. Milk from the fully housed/mid-lactation ewes had a higher overall FV than milk from pasture-grazed/late-lactation ewes. This would likely influence the sheepy flavor of sheep milk products (e.g., cheese, yogurt, powder).

\section{ACKNOWLEDGMENTS}

This work was part of the research program "Boosting Exports of the Emerging New Zealand Dairy Sheep Industry" funded by Ministry of Business, Innovation \& Employment, New Zealand (contract No. C10X1305). The authors acknowledge Spring Sheep Milk Co. (Auckland, New Zealand) for performing the trial and providing the milk samples, Poppy Miller (AgResearch Ltd., Palmerston North, New Zealand) for statistical analysis, and Michael Agnew (AgResearch Ltd.) for assisting in the development of the vBCFA analysis method. The authors have no conflicts of interest.

\section{REFERENCES}

Agricultural Research Council and Commonwealth Bureaux. 1980. The Nutrient Requirements of Ruminant Livestock: Technical Review. Commonwealth Agricultural Bureaux for the Agricultural Research Council, London, UK.

Andrés, S., E. Jaramillo, R. Bodas, C. Blanco, J. Benavides, P. Fernández, E. P. González, J. Frutos, Á. Belenguer, S. López, and F. J. Giráldez. 2018. Grain grinding size of cereals in complete pelleted diets for growing lambs: Effects on ruminal microbiota and fermentation. Small Rumin. Res. 159:38-44. https://doi.org/ 10.1016/j.smallrumres.2017.12.009.

Aschenbach, J. R., N. B. Kristensen, S. S. Donkin, H. M. Hammon, and G. B. Penner. 2010. Gluconeogenesis in dairy cows: The secret of making sweet milk from sour dough. IUBMB Life 62:869-877. https://doi.org/10.1002/iub.400.

Benjamini, Y., and Y. Hochberg. 1995. Controlling the false discovery rate: A practical and powerful approach to multiple testing. J. R. Stat. Soc. Series B 57:289-300. https://doi.org/10.1111/j.2517 -6161.1995.tb02031.x.

Bliss, A., C. Chylinski, D. Luo, K. Schütz, K. Lowe, S. Peterson, D. Stevens, T. MacDonald, and S. McCoard. 2018. The impact of different management systems on behaviour and milk production of dairy ewes in different stages of lactation; A case study. Proc. N. Z. Soc. Anim. Prod. 78:116-121.

Buccioni, A., M. Pauselli, S. Minieri, V. Roscini, F. Mannelli, S. Rapaccini, P. Lupi, G. Conte, A. Serra, A. Cappucci, L. Brufani, F. Ciucci, and M. Mele. 2017. Chestnut or quebracho tannins in the diet of grazing ewes supplemented with soybean oil: Effects on animal performances, blood parameters and fatty acid composition of plasma and milk lipids. Small Rumin. Res. 153:23-30. https:// doi.org/10.1016/j.smallrumres.2017.05.006.

Buccioni, A., A. Serra, S. Minieri, F. Mannelli, A. Cappucci, D. Benvenuti, S. Rapaccini, G. Conte, and M. Mele. 2015. Milk production, composition, and milk fatty acid profile from grazing sheep fed diets supplemented with chestnut tannin extract and extruded linseed. Small Rumin. Res. 130:200-207. https://doi.org/10.1016/ j.smallrumres.2015.07.021.

Cabiddu, A., M. Decandia, M. Addis, G. Piredda, A. Pirisi, and G. Molle. 2005. Managing Mediterranean pastures in order to enhance the level of beneficial fatty acids in sheep milk. Small Rumin. Res. 59:169-180. https://doi.org/10.1016/j.smallrumres.2005.05.005. 
Caja, G., and F. Bocquier. 2000. Effects of nutrition on the composition of sheep's milk. Cahiers Options Méditerranéennes 52:59-74.

Carreau, J. P., and J. P. Dubacq. 1978. Adaptation of a macro-scale method to the micro-scale for fatty acid methyl transesterification of biological lipid extracts. J. Chromatogr. A 151:384-390. https:/ /doi.org/10.1016/S0021-9673(00)88356-9.

Corson, D. C., G. C. Waghorn, M. J. Ulyatt, and J. Lee. 1999. NIRS: Forage analysis and livestock feeding. Proc. NZ Grassland Assoc. $61: 127-132$.

Brennand, C. P., J. K. Ha, and R. C. Lindsay. 1989. Aroma properties and thresholds of some branched-chain and other minor volatile fatty acids occurring in milkfat and meat lipids. J. Sens. Stud. 4:105-120. https://doi.org/10.1111/j.1745-459X.1989.tb00461.x.

Chikwanha, O. C., P. Vahmani, V. Muchenje, M. E. R. Dugan, and C. Mapiye. 2018. Nutritional enhancement of sheep meat fatty acid profile for human health and wellbeing. Food Res. Int. 104:25-38. https://doi.org/10.1016/j.foodres.2017.05.005

Chilliard, Y., A. Ferlay, R. M. Mansbridge, and M. Doreau. 2000 Ruminant milk fat plasticity: Nutritional control of saturated, polyunsaturated, trans and conjugated fatty acids. Ann. Zootech. 49:181-205. https://doi.org/10.1051/animres:2000117.

Destaillats, F., J. Trottier, J. G. Galvez, and P. Angers. 2005. Analysis of $\alpha$-linolenic acid biohydrogenation intermediates in milk fat with emphasis on conjugated linolenic acids. J. Dairy Sci. 88:3231-3239. https://doi.org/10.3168/jds.S0022-0302(05)73006-X.

Dewhurst, R. J., K. Shingfield, M. R. Lee, and N. D. Scollan. 2006. Increasing the concentrations of beneficial polyunsaturated fatty acids in milk produced by dairy cows in high-forage systems. Anim. Feed Sci. Technol. 131:168-206. https://doi.org/10.1016/j .anifeedsci.2006.04.016.

Duchateau, L., P. Janssen, and J. Rowlands. 1998. Linear Mixed Models. An Introduction with Applications in Veterinary Research. International Livestock Research Institute, Nairobi, Kenya.

Duncan, W. R. H., and G. A. Garton. 1978. Differences in the proportions of branched-chain fatty acids in subcutaneous triacylglycerols of barley-fed ruminants. Br. J. Nutr. 40:29-33. https://doi.org/ 10.1079/BJN19780092.

Ellison, M. J., G. C. Conant, W. R. Lamberson, R. R. Cockrum, K. J. Austin, D. C. Rule, and K. M. Cammack. 2017. Diet and feed efficiency status affect rumen microbial profiles of sheep. Small Rumin. Res. 156:12-19. https://doi.org/10.1016/j.smallrumres 2017.08.009.

Frank, D., P. Watkins, A. Ball, R. Krishnamurthy, U. Piyasiri, J. Sewell, J. Ortuño, J. Stark, and R. Warner. 2016. Impact of brassica and lucerne finishing feeds and intramuscular fat on lamb eating quality and flavor. A cross-cultural study using Chinese and non-Chinese Australian consumers. J. Agric. Food Chem. 64:68566868. https://doi.org/10.1021/acs.jafc.6b02018.

Fuertes, J. A., C. Gonzalo, J. Carriedo, and F. San Primitivo. 1998. Parameters of test day milk yield and milk components for dairy ewes. J. Dairy Sci. 81:1300-1307. https://doi.org/10.3168/jds .S0022-0302(98)75692-9.

Garg, M. R., P. L. Sherasia, B. M. Bhanderi, B. T. Phondba, S. K. Shelke, and H. P. S. Makkar. 2013. Effects of feeding nutritionally balanced rations on animal productivity, feed conversion efficiency, feed nitrogen use efficiency, rumen microbial protein supply, parasitic load, immunity and enteric methane emissions of milking animals under field conditions. Anim. Feed Sci. Technol. 179:24-35. https://doi.org/10.1016/j.anifeedsci.2012.11.005.

Gebreyowhans, S., J. Lu, S. Zhang, X. Pang, and J. Lv. 2019. Dietary enrichment of milk and dairy products with n-3 fatty acids: A review. Int. Dairy J. 97:158-166. https://doi.org/10.1016/j.idairyj 2019.05.011.

Grant, R. J., and L. F. Ferraretto. 2018. Silage review: Silage feeding management: Silage characteristics and dairy cow feeding behavior. J. Dairy Sci. 101:4111-4121. https://doi.org/10.3168/jds.2017 $-13729$

Ha, J. K., and R. C. Lindsay. 1990. Distribution of volatile branchedchain fatty acids in perinephric fats of various red meat species. Lebensm. Wiss. Technol. 23:433-440.
Haenlein, G. F. W., and W. L. Wendorff. 2008. Sheep milk. Pages 137-194 in Handbook of Milk of Non-Bovine Mammals. Blackwell Publishing Professional, Hoboken, NJ.

Hur, S. J., H. S. Kim, Y. Y. Bahk, and Y. Park. 2017. Overview of conjugated linoleic acid formation and accumulation in animal products. Livest. Sci. 195:105-111. https://doi.org/10.1016/j.livsci .2016.11.016.

Kaffarnik, S., C. Heid, Y. Kayademir, D. Eibler, and W. Vetter. 2015. High enantiomeric excess of the flavor relevant 4-alkyl-branched fatty acids in milk fat and subcutaneous adipose tissue of sheep and goat. J. Agric. Food Chem. 63:469-475. https://doi.org/10 $.1021 /$ jf505452u.

Kaffarnik, S., Y. Kayademir, C. Heid, and W. Vetter. 2014. Concentrations of volatile 4-alkyl-branched fatty acids in sheep and goat milk and dairy products. J. Food Sci. 79:C2209-C2214. https:// doi.org/10.1111/1750-3841.12673.

Kotsampasi, B., E. Tsiplakou, C. Christodoulou, A. Mavrommatis, C. Mitsiopoulou, C. Karaiskou, E. Sossidou, N. Fragioudakis, I. Kapsomenos, V. A. Bampidis, V. Christodoulou, and G. Zervas. 2018. Effects of dietary orange peel essential oil supplementation on milk yield and composition, and blood and milk antioxidant status of dairy ewes. Anim. Feed Sci. Technol. 245:20-31. https://doi.org/ 10.1016/j.anifeedsci.2018.08.007.

Kuchtík, J., K. Šustová, T. Urban, and D. Zapletal. 2008. Effect of the stage of lactation on milk composition, its properties and the quality of rennet curdling in East Friesian ewes. Czech J. Anim. Sci. 53:55-63. https://doi.org/10.17221/333-CJAS.

Massart-Leën, A. M., E. Roets, G. Peeters, and R. Verbeke. 1983. Propionate for fatty acid synthesis by the mammary gland of the lactating goat. J. Dairy Sci. 66:1445-1454. https://doi.org/10.3168/ jds.S0022-0302(83)81958-4.

Mioč, B., Z. Prpić, N. Antunac, Z. Antunović, D. Samaržija, I. Vnučec, and V. Pavić. 2009. Milk yield and quality of Cres sheep and their crosses with Awassi and East Friesian sheep. Mljekarstvo $59: 217-224$.

Morand-Fehr, P., V. Fedele, M. Decandia, and Y. Le Frileux. 2007. Influence of farming and feeding systems on composition and quality of goat and sheep milk. Small Rumin. Res. 68:20-34. https:// doi.org/10.1016/j.smallrumres.2006.09.019.

Nasrollahi, S. M., A. Zali, G. R. Ghorbani, M. Moradi Shahrbabak, and M. Heydari Soltan Abadi. 2017. Variability in susceptibility to acidosis among high producing mid-lactation dairy cows is associated with rumen $\mathrm{pH}$, fermentation, feed intake, sorting activity, and milk fat percentage. Anim. Feed Sci. Technol. 228:72-82. https://doi.org/10.1016/j.anifeedsci.2017.03.007.

Novotná, L., J. Kuchtík, K. Sustová, D. Zapletal, and R. Filipcík. 2009. Effects of lactation stage and parity on milk yield, composition and properties of organic sheep milk. J. Appl. Anim. Res. 36:71-76. https://doi.org/10.1080/09712119.2009.9707034.

Oravcová, M., M. Margetín, D. Peskovicova, J. Dano, M. Milerski, L. Hetényi, and P. Polák. 2006. Factors affecting milk yield and ewe's lactation curves estimated with test-day models. Czech J. Anim. Sci. 51:483-490. https://doi.org/10.17221/3968-CJAS.

Pavić, V., N. Antunac, B. Mioč, A. Ivanković, and J. Havranek. 2002. Influence of stage of lactation on the chemical composition and physical properties of sheep milk. Czech J. Anim. Sci. 47:80-84.

Pulina, G., A. Nudda, N. P. P. Macciotta, G. Battacone, S. P. Giacomo Rassu, and A. Cannas. 2007. Non-nutritional factors affecting lactation persistency in dairy ewes: A review. Ital. J. Anim. Sci. 6:115-141. https://doi.org/10.4081/ijas.2007.115.

Raynal-Ljutovac, K., G. Lagriffoul, P. Paccard, I. Guillet, and Y. Chilliard. 2008. Composition of goat and sheep milk products: An update. Small Rumin. Res. 79:57-72. https://doi.org/10.1016/ j.smallrumres.2008.07.009.

Rugoho, I., Y. Liu, and R. J. Dewhurst. 2014. Analysis of major fatty acids in milk produced from high-quality grazed pasture. N. Z. J. Agric. Res. 57:165-179. https://doi.org/10.1080/00288233.2014 .899505 .

Sahan, N., D. Say, and A. Kaçar. 2005. Changes in chemical and mineral contents of Awassi ewes' milk during lactation. Turk. J. Vet. Anim. Sci. 29:589-593. 
Salles, C., N. Sommerer, C. Septier, S. Issanchou, C. Chabanet, A. Garem, and J. L. L. Quéré. 2002. Goat cheese flavor: Sensory evaluation of branched-chain fatty acids and small peptides. J. Food Sci. 67:835-841. https://doi.org/10.1111/j.1365-2621.2002.tb10686.x.

Salvatore, L., D. Allen, K. L. Butler, D. Tucman, A. Elkins, D. W. Pethick, and F. R. Dunshea. 2007. Factors affecting the concentration of short branched-chain fatty acids in sheep fat. Aust. J. Exp. Agric. 47:1201-1207. https://doi.org/10.1071/EA07037.

Sanz Sampelayo, M. R., Y. Chilliard, P. Schmidely, and J. Boza. 2007. Influence of type of diet on the fat constituents of goat and sheep milk. Small Rumin. Res. 68:42-63. https://doi.org/10.1016/ j.smallrumres.2006.09.017.

Sevi, A., and M. Caroprese. 2012. Impact of heat stress on milk production, immunity and udder health in sheep: A critical review. Small Rumin. Res. 107:1-7. https://doi.org/10.1016/j.smallrumres .2012.07.012.

Svennerholm, L., and P. Fredman. 1980. A procedure for the quantitative isolation of brain gangliosides. Biochim. Biophys. Acta 617:97-109. https://doi.org/10.1016/0005-2760(80)90227-1.

Teng, F., M. G. Reis, Y. Ma, and L. Day. 2018. Effects of season and industrial processes on volatile 4-alkyl-branched chain fatty acids in sheep milk. Food Chem. 260:327-335. https://doi.org/10.1016/ j.foodchem.2018.04.011.
Teng, F., P. Wang, L. Yang, Y. Ma, and L. Day. 2017. Quantification of fatty acids in human, cow, buffalo, goat, yak, and camel milk using an improved one-step GC-FID method. Food Anal. Methods 10:2881-2891. https://doi.org/10.1007/s12161-017-0852-z.

Viechtbauer, W. 2005. Bias and efficiency of meta-analytic variance estimators in the random-effects model. J. Educ. Behav. Stat 30:261-293. https://doi.org/10.3102/10769986030003261.

Vlaeminck, B., V. Fievez, A. R. J. Cabrita, A. J. M. Fonseca, and R. J. Dewhurst. 2006. Factors affecting odd- and branched-chain fatty acids in milk: A review. Anim. Feed Sci. Technol. 131:389-417. https://doi.org/10.1016/j.anifeedsci.2006.06.017.

Watkins, P. J., D. Frank, T. K. Singh, O. A. Young, and R. D. Warner. 2013. Sheepmeat flavor and the effect of different feeding systems: A review. J. Agric. Food Chem. 61:3561-3579. https://doi.org/10 $.1021 /$ jf303768e.

Wong, E., L. N. Nixon, and C. B. Johnson. 1975. Volatile medium chain fatty acids and mutton flavor. J. Agric. Food Chem. 23:495498. https://doi.org/10.1021/jf60199a044.

Young, O. A., G. A. Lane, A. Priolo, and K. Fraser. 2003. Pastoral and species flavour in lambs raised on pasture, lucerne or maize. J. Sci. Food Agric. 83:93-104. https://doi.org/10.1002/jsfa.1282. 